\title{
Nevskia soli sp. nov., isolated from soil cultivated with Korean ginseng
}

\author{
Hang-Yeon Weon, ${ }^{1}$ Byung-Yong Kim, ${ }^{2}$ Jung-A Son, ${ }^{1}$ Myung-Hee Song, ${ }^{2}$ \\ Soon-Wo Kwon, ${ }^{2}$ Seung-Joo Go ${ }^{2}$ and Erko Stackebrandt ${ }^{3}$
}

Correspondence

Soon-Wo Kwon

swkwon@rda.go.kr

\author{
${ }^{1}$ Applied Microbiology Division, National Institute of Agricultural Science and Technology, \\ Rural Development Administration (RDA), Suwon 441-707, Republic of Korea \\ ${ }^{2}$ Korean Agricultural Culture Collection (KACC), Microbial Genetics Division, National Institute of \\ Agricultural Biotechnology, RDA, Suwon 441-707, Republic of Korea \\ ${ }^{3} \mathrm{DSMZ}$ - Deutsche Sammlung von Mikroorganismen und Zellkulturen GmbH, Inhoffenstr. 7b, \\ D-38124 Braunschweig, Germany
}

\begin{abstract}
A Gram-negative bacterium, designated strain GR15-1 ${ }^{\top}$, was isolated from a field cultivated with Korean ginseng. Cells were strictly aerobic, motile with multipolar flagella and rod-shaped. The strain grew optimally at $25-28^{\circ} \mathrm{C}$ and $\mathrm{pH}$ 6.0-7.0. The predominant fatty acids of strain GR15-1 ${ }^{\top}$ were $\mathrm{C}_{18: 1} \omega 7 c, \mathrm{C}_{16: 0}$ and summed feature $2\left(\mathrm{C}_{14: 0} 3-\mathrm{OH}\right.$ and/or iso- $\left.\mathrm{C}_{16: 1} \mathrm{I}\right)$. The major isoprenoid quinone was ubiquinone 8 . The $G+C$ content of the genomic DNA was $63.9 \mathrm{~mol} \%$. Phylogenetic analysis showed that strain GR15-1 ${ }^{\top}$ formed a phyletic cluster with Nevskia ramosa Soe $1^{\top}$, with a $16 \mathrm{~S}$ rRNA gene sequence similarity of $96.8 \%$. Based on phenotypic, chemotaxonomic and phylogenetic features, strain GR15-1 ${ }^{\top}$ represents a novel species within the genus Nevskia, for which the name Nevskia soli sp. nov. is proposed. The type strain is GR15-1 ${ }^{\top}\left(=\right.$ KACC $11703^{\top}=$ DSM $\left.19509^{\top}\right)$.
\end{abstract}

Although the genus Nevskia were first reported by Famintzin (1892), pure cultures were not available for many years. Stürmeyer et al. (1998) isolated pure cultures from a bog lake and a freshwater ditch, and some taxonomic properties were elucidated. The genus Nevskia was classified into the family Xanthomonadaceae within the Gammaproteobacteria. This genus, with the genus Hydrocarboniphaga, formed a deeply branched cluster separable from other member genera of the family Xanthomonadaceae such as Xanthomonas, Rhodanobacter and Stenotrophomonas (Stürmeyer et al., 1998; Palleroni et al., 2004).

In the course of the study of bacterial diversity in fields cultivated with Korean ginseng (Panax ginseng C. A. Meyer), a novel bacterial strain, GR15- $1^{\mathrm{T}}$, was isolated in the Yeongju region of Korea. Phylogenetically, this strain clustered with Nevskia ramosa and Hydrocarboniphaga effusa.

To investigate the morphological and some physiological characteristics of strain GR $15-1^{\mathrm{T}}$, the strain was routinely cultivated on R2A medium at $28{ }^{\circ} \mathrm{C}$. Unless otherwise indicated, phenotypic characteristics were studied using standard procedures (Smibert \& Krieg, 1994; Weon et al., 2006). After 3 days incubation at $28^{\circ} \mathrm{C}$, cell morphology was examined by light microscopy (AXIO; Zeiss) and transmission electron microscopy (TEM). For TEM

The GenBank/EMBL/DDBJ accession number for the 16S rRNA gene sequence of strain GR15- $1^{\top}$ is EF178286. observation, cells were negatively stained with $0.5 \%(\mathrm{w} / \mathrm{v})$ uranyl acetate and examined with an LEO model 912AB electron microscope. For the various physiological tests, API 20NE and API ID 32GN test strips (bioMérieux) were used according to the manufacturer's instructions.

Isolation of chromosomal DNA, PCR amplification and direct sequencing of the purified product were carried out as described previously (Weon et al., 2006). The resultant $16 \mathrm{~S}$ rRNA gene sequence (1421 bp) was aligned with corresponding sequences of some members classified in the family Xanthomonadaceae retrieved from the GenBank database using the CLUSTAL w program (Thompson et al., 1994). A phylogenetic tree was produced using the software package MEGA version 3.1 (Kumar et al., 2004). Distances (using distance options according to Kimura's two-parameter model) and clustering using the neighbour-joining and maximum-parsimony methods were determined by using bootstrap values based on 1000 replicates.

The $\mathrm{G}+\mathrm{C}$ content of the genomic DNA was determined by HPLC analysis of deoxyribonucleosides as described by Mesbah et al. (1989) using a reversed-phase column (Supelcosil LC-18S; Supelco). Cellular fatty acids were determined for a culture grown on $\mathrm{R} 2 \mathrm{~A}$ at $28{ }^{\circ} \mathrm{C}$ for 2 days and were extracted, methylated and analysed using the standard MIDI (Microbial Identification) system (Sasser, 1990). Isoprenoid quinones were examined according to Groth et al. (1996). 

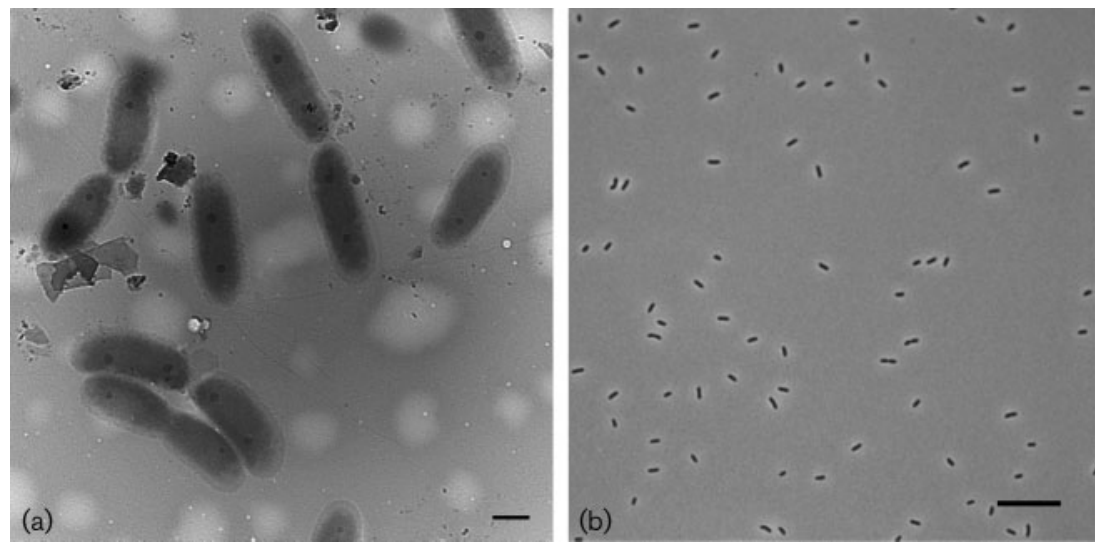

Fig. 1. Morphology of cells of strain GR15-1 ${ }^{\top}$ after growth for 3 days on R2A. Transmission electron micrograph (a) and phase-contrast micrograph (b). Bars, $500 \mathrm{~nm}$ (a) and $10 \mu \mathrm{m}$ (b).

Strain GR15-1 ${ }^{\mathrm{T}}$ grew on R2A, but did not grow on nutrient agar, trypticase soy agar or MacConkey agar (all from Difco). Cells of GR $15-1^{\mathrm{T}}$ were motile with multiple polar flagella and rod-shaped, $0.5 \mu \mathrm{m}$ wide and $1.5-2.0 \mu \mathrm{m}$ long

Table 1. Phenotypic characteristics that differentiate strain GR $15-1^{\top}$ from other related type strains

Strains: 1, GR15-1 $1^{\mathrm{T}}$; 2, N. ramosa DSM $11499^{\mathrm{T}}$; 3, H. effusa DSM $16095^{\mathrm{T}}$. Data are from this study unless indicated. All strains are strictly aerobic, Gram-negative and motile and do not assimilate trisodium citrate. All strains hydrolyse Tween 80. All strains are negative for nitrate reduction, indole production, glucose fermentation, arginine dihydrolase, urease and aesculin hydrolysis (API $20 \mathrm{NE}$ test strips). None of the strains assimilates D-glucose, L-arabinose, Dmannose, D-mannitol, $\mathrm{N}$-acetylglucosamine, maltose, potassium gluconate, capric acid, adipic acid, phenylacetic acid, L-rhamnose, D-ribose, inositol, itaconic acid, suberic acid, sodium malonate, sodium acetate, L-alanine, potassium 5-ketogluconate, 3-hydroxybenzoic acid, L-serine, salicin, melibiose, L-fucose, D-sorbitol, valeric acid, L-histidine, potassium 2-ketogluconate, 4-hydroxybenzoic acid or L-proline (API $20 \mathrm{NE}$ and API ID 32GN test strips). +, Positive; - , negative; $\mathrm{W}$, weakly positive; ND, no data available.

\begin{tabular}{|lccc|}
\hline Characteristic & $\mathbf{1}$ & $\mathbf{2}$ & $\mathbf{3}$ \\
\hline Flagella & Multipolar & ND & $\begin{array}{c}\text { One polar, subpolar } \\
\text { or, more rarely, } \\
\text { lateral insertion }\end{array}$ \\
Catalase/oxidase & $+/+$ & w/ ${ }^{b}$ & ND/ND \\
Gelatin hydrolysis & - & + & + \\
$\beta$-Galactosidase & - & + & - \\
Assimilation of: & & & + \\
Malic acid & - & - & + \\
Sucrose & - & - & + \\
Lactic acid & - & - & + \\
Glycogen & + & - & + \\
Propionic acid & - & - & + \\
3-Hydroxybutyric acid & - & - & $60-61^{a}$ \\
DNA G+C content & 63.9 & $67.8^{b}$ & \\
(mol\%) & & & \\
\hline
\end{tabular}

${ }^{\star}$ Data from: a, Palleroni et al. (2004); b, Stürmeyer et al. (1998).
(Fig. 1). Phenotypic characteristics that differentiate strain GR15- $1^{\mathrm{T}}$ from related species are listed in Table 1.

According to the neighbour-joining tree (Fig. 2), strain GR15- $1^{\mathrm{T}}$ was placed within a cluster of two uncultured bacteria, uncultured eubacterium WD284 and uncultured rape rhizosphere bacterium wr0008, which were respectively cloned from polychlorinated biphenyl-polluted soil (Nogales et al., 2001) and the rhizoplane of oilseed rape (Kaiser et al., 2001). This cluster forms a deeply branching clade with another cluster including $N$. ramosa Soel ${ }^{\mathrm{T}}$ on the basis of a considerable bootstrap value $(86 \%)$. Strain GR15- $1^{\mathrm{T}}$ shares $96.8 \% 16 \mathrm{~S}$ rRNA gene sequence identity with $N$. ramosa Soe $1^{\mathrm{T}}$ and $94.2 \%$ sequence identity with $H$. effusa $\mathrm{AP} 103^{\mathrm{T}}$. The maximum-parsimony tree showed a

Table 2. Cellular fatty acid compositions of strain GR15-1 ${ }^{\top}$ and related strains

Strains: 1, GR15-1 ${ }^{\mathrm{T}}$; 2, N. ramosa DSM $11499^{\mathrm{T}}$; 3, H. effusa DSM $16095^{\mathrm{T}}$. Data are from this study. Cells for all strains were harvested after growth on R2A at $28{ }^{\circ} \mathrm{C}$ for 2 days. Fatty acids representing less than $1.0 \%$ were omitted.

\begin{tabular}{|lrcc|}
\hline Fatty acid & $\mathbf{1}$ & $\mathbf{2}$ & $\mathbf{3}$ \\
\hline $\mathrm{C}_{12: 0}$ 3-OH & 7.6 & 6.1 & 9.1 \\
$\mathrm{C}_{12: 0}$ - & - & 2.7 & 1.4 \\
$\mathrm{C}_{14: 0}$ & 5.3 & 11.8 & 2.3 \\
$\mathrm{C}_{14: 0} 2-\mathrm{OH}$ & 1.0 & 4.5 & 1.9 \\
$\mathrm{C}_{16: 0}$ & 17.5 & 8.9 & 18.1 \\
$\mathrm{C}_{16: 0} 3-\mathrm{OH}$ & 2.2 & - & - \\
$\mathrm{C}_{16: 0} \mathrm{~N}$ alcohol & 1.1 & - & - \\
iso- $_{16: 0}$ & 1.2 & - & - \\
$\mathrm{C}_{17: 0}$ cyclo & 6.3 & - & - \\
$\mathrm{C}_{18: 1} 2-\mathrm{OH}$ & - & 3.3 & - \\
$\mathrm{C}_{18: 1} \omega 7 c$ & 31.1 & 28.7 & 44.7 \\
$\mathrm{C}_{19: 0} \omega 8 c$ cyclo & 3.9 & - & - \\
Summed feature $2^{*}$ & 10.3 & 2.0 & 1.7 \\
Summed feature $3^{*}$ & 9.9 & 29.2 & 16.4 \\
\hline
\end{tabular}

${ }^{*}$ Summed feature 2 comprises $\mathrm{C}_{14: 0} 3-\mathrm{OH}$ and/or iso- $\mathrm{C}_{16: 1} \mathrm{I}$. Summed feature 3 comprises iso- $\mathrm{C}_{15: 0} 2-\mathrm{OH}$ and/or $\mathrm{C}_{16: 1} \omega 7 c$. 


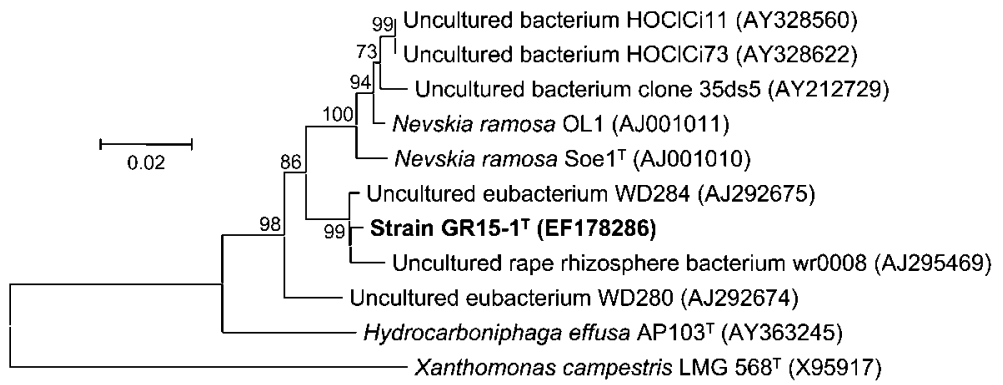

Fig. 2. Neighbour-joining phylogenetic tree (Saitou \& Nei, 1987) based on 16S rRNA gene sequences, showing the position of strain GR15-1 $1^{\top}$. Bootstrap values are shown as percentages of 1000 replicates (only values above $50 \%$ are shown). GenBank accession numbers are shown in parentheses. Bar, 0.02 substitutions per nucleotide position.

very similar topology for the novel strain and other related species (not shown).

The DNA G + C content of strain GR15-1 ${ }^{\mathrm{T}}$ was $63.9 \mathrm{~mol} \%$. Major cellular fatty acids $(>10 \%)$ identified from strain GR15- $1^{\mathrm{T}}$ were $\mathrm{C}_{18: 1} \omega 7 c, \mathrm{C}_{16: 0}$ and summed feature 2 . The full fatty acid profile is detailed in Table 2. The major isoprenoid quinone was ubiquinone $8(\mathrm{Q}-8)$.

Strain GR $15-1^{\mathrm{T}}$ can be clearly differentiated from its closest relative, N. ramosa DSM $11499^{\mathrm{T}}$, by means of some phenotypic properties such as the production of oxidase and the inability to hydrolyse gelatin or to produce $\beta$ galactosidase and by differences in the fatty acid compositions (Tables 1 and 2). However, molecular data such as its high 16S rRNA gene sequence similarity and similar $\mathrm{G}+\mathrm{C}$ content confirmed the affiliation of strain GR $15-1^{\mathrm{T}}$ to the genus Nevskia. On the basis of the phylogenetic evidence together with the phenotypic characteristics presented in this study, strain GR $15-1^{\mathrm{T}}$ represents a novel species within the genus Nevskia, for which the name Nevskia soli sp. nov. is proposed.

\section{Description of Nevskia soli sp. nov.}

Nevskia soli (so'li. L. neut. gen. n. soli of soil, the source of the type strain).

Cells are Gram-negative, motile, non-spore-forming and rod-shaped $(0.5 \times 1.5-2.0 \mu \mathrm{m})$. Colonies are white, circular and convex with clear margins after 4 days on R2A medium. Growth occurs at $15-30{ }^{\circ} \mathrm{C}$ (optimum 25$28{ }^{\circ} \mathrm{C}$ ) and $\mathrm{pH} 4.0-7.0$ (optimum $\mathrm{pH}$ 6.0-7.0). Grows in the absence of $\mathrm{NaCl}$, but does not grow on $2 \% \mathrm{NaCl}$. Tween 80 and starch are hydrolysed. Hydrolysis of casein, chitin, CM-cellulose, DNA, pectin and tyrosine is not observed. Major isoprenoid quinone is Q-8. Predominant cellular fatty acids $(>10 \%)$ are $\mathrm{C}_{18: 1} \omega 7 c, \mathrm{C}_{16: 0}$ and summed feature $2\left(\mathrm{C}_{14: 0} 3-\mathrm{OH}\right.$ and/or iso- $\left.\mathrm{C}_{16: 1} \mathrm{I}\right)$. DNA $\mathrm{G}+\mathrm{C}$ content of the type strain is $63.9 \mathrm{~mol} \%$ (HPLC).

The type strain, GR15- $1^{\mathrm{T}} \quad\left(=\mathrm{KACC} 11703^{\mathrm{T}}=\mathrm{DSM}\right.$ $19509^{\mathrm{T}}$ ), was isolated from soil cultivated with Korean ginseng in the Yeongju region of Korea.

\section{Acknowledgements}

We are grateful to Dr Elke Lang (DSMZ) for providing Nevskia ramosa DSM $11499^{\mathrm{T}}$. This study was supported by the National
Institute of Agricultural Biotechnology (NIAB grant no. 06-4-11-191), Rural Development Administration, Republic of Korea.

\section{References}

Famintzin, A. (1892). Eine neue Bacterienform: Nevskia ramosa. Bull Acad Imp Sci St Petersbourg New Ser 2 34, 481-486 (in German).

Groth, I., Schumann, P., Weiss, N., Martin, K. \& Rainey, F. A. (1996). Agrococcus jenensis gen. nov., sp. nov., a new genus of actinomycetes with diaminobutyric acid in the cell wall. Int J Syst Bacteriol 46, 234-239.

Kaiser, O., Puhler, A. \& Selbitschka, W. (2001). Phylogenetic analysis of microbial diversity in the rhizoplane of oilseed rape (Brassica napus cv. Westar) employing cultivation-dependent and cultivation-independent approaches. Microb Ecol 42, 136-149.

Kumar, S., Tamura, K. \& Nei, M. (2004). MEGA 3: integrated software for molecular evolutionary genetics analysis and sequence alignment. Brief Bioinform 5, 150-163.

Mesbah, M., Premachandran, U. \& Whitman, W. B. (1989). Precise measurement of the $\mathrm{G}+\mathrm{C}$ content of deoxyribonucleic acid by highperformance liquid chromatography. Int J Syst Bacteriol 39, 159-167.

Nogales, B., Moore, E. R. B., Llobet-Brossa, E., Rosselló-Mora, R., Amann, R. \& Timmis, K. N. (2001). Combined use of $16 \mathrm{~S}$ ribosomal DNA and 16S rRNA to study the bacterial community of polychlorinated biphenyl-polluted soil. Appl Environ Microbiol 67, 1874-1884.

Palleroni, N. J., Port, A. M., Chang, H. K. \& Zylstra, G. J. (2004). Hydrocarboniphaga effusa gen. nov., sp. nov., a novel member of the $\gamma$-Proteobacteria active in alkane and aromatic hydrocarbon degradation. Int J Syst Evol Microbiol 54, 1203-1207.

Saitou, N. \& Nei, M. (1987). The neighbor-joining method: a new method for reconstructing phylogenetic trees. Mol Biol Evol 4, 406-425.

Sasser, M. (1990). Identification of bacteria by gas chromatography of cellular fatty acids. Technical Note 101. Newark, DE: MIDI Inc.

Smibert, R. M. \& Krieg, N. R. (1994). Phenotypic characterization. In Methods for General and Molecular Bacteriology, pp. 607-654. Edited by P. Gerhardt, R. G. E. Murray, W. A. Wood \& N. R. Krieg. Washington, DC: American Society for Microbiology.

Stürmeyer, H., Overmann, J., Babenzien, H. D. \& Cypionka, H. (1998). Ecophysiological and phylogenetic studies of Nevskia ramosa in pure culture. Appl Environ Microbiol 64, 1890-1894.

Thompson, J. D., Higgins, D. G. \& Gibson, T. J. (1994). CLUSTAL W: improving the sensitivity of progressive multiple sequence alignment through sequence weighting, position-specific gap penalties and weight matrix choice. Nucleic Acids Res 22, 4673-4680.

Weon, H.-Y., Kim, B.-Y., Yoo, S.-H., Lee, S.-Y., Kwon, S.-W., Go, S.-J. \& Stackebrandt, E. (2006). Niastella koreensis gen. nov., sp. nov. and Niastella yeongjuensis sp. nov., novel members of the phylum Bacteroidetes, isolated from soil cultivated with Korean ginseng. Int J Syst Evol Microbiol 56, 1777-1782. 